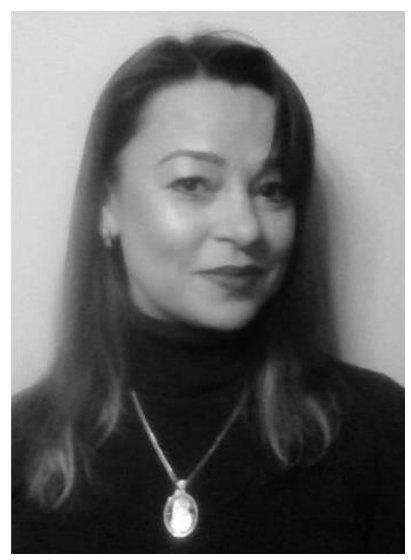

\title{
Оксана Вайцеховська,
}

кандичат юридичних наук, Аоцент, Аочент кафедри європейського права та порівняльного правознавства

Чернівецького національного університету імені Юрія Федьковича

УДК 341.1/8

\section{Фінансова національна безпека як складова фінансового суверенітету держави}

В умовах швидкої глобалізації міжнародної фінансової системи зв'язок економіки України з світовою економікою, i. експортна орієнтація, від'ємний платіжний баланс, а відповідно і постійні зовнішні запозичення, створюють значні небезпеки для національної фінансової системи. В умовах фінансово-економічної кризи пріоритетним напрямом діяльності держави є проведення скоординованої політики та вироблення стратегії щодо зниження впливу кризових явищ у фінансовому секторі. Враховуючи масштаб, глибину і тривалість кризових явищ у фінансовій сфері, а також ступінь ї негативного впливу на процеси, що відбуваються у вітчизняній економіці, потребують вдосконалення підходи до формування системи фінансової безпеки України. Національна фінансова безпека особливо тісно пов'язана 3 державним фінансовим суверенітетом, оскільки в разі відсутності першого ставиться під сумнів наявність другого. Зазначене обумовлює актуальність дослідження даної проблематики, зокрема тих зовнішніх та внутрішніх факторів, що можуть призвести до створення різного роду загроз національ- ній фінансовій безпеці, та шляхів їх мінімізації.

Метою статті є провести правовий аналіз основних факторів, які впливають на національну безпеку держави, та дослідити чинники, що обмежують державний фінансовий суверенітет.

Забезпечення з боку держави захисту життєво важливих (ключових) інтересів держави, регіонів, підприємницьких структур та громадян у фінансовій сфері від впливу негативних чинників $€$ однією 3 головних внутрішніх функцій держави. Глобалізація в міжнародній фінансовій системі, яка підвищила взаємозалежність національних валют держав світу та вразливість національних фінансових систем від фінансових криз в окремих регіонах світу, поставили на перший план питання національної фінансової безпеки та актуалізували важливість захисту національних інтересів держави у фінансовій сфері. Чутливість національних фінансових систем від світових фінансових криз та їх залежність від зовнішнього впливу обумовили тенденцію щодо прийняття на державному рівні концепцій забезпечення націо- 
нальної безпеки у фінансовій сфері [наприклад, 1], в якій державними органами закріплюється система принципів та засобів реалізації ключових інтересів у фінансовій сфері держави та захисту від внутрішніх та зовнішніх загроз.

Питання фінансової безпеки держави, зокрема іiі забезпечення, впливає одночасно на внутрішню функцію держави та тісно пов'язане 3 iî зовнішньою функцією, яку держави виконують під час міжнародного співробітництва в сфері фінансів. Відповідно до Розпорядження Кабінету Міністрів України «Про схвалення Концепції забезпечення національної безпеки у фінансовій сфері» від 2012 року до чинників, що можуть призвести до зовнішніх загроз національній безпеці у фінансовій сфері належать: значна залежність від зовнішніх кредиторів, обмеженість доступу до міжнародних фінансових ринків, значна залежність від експортно-імпортної діяльності, погіршення стану зовнішньої торгівлі, зростання дефіциту платіжного балансу, зокрема рахунку поточних операцій, та вплив світових фінансових криз на фінансову систему держави [1]. Також, на наш погляд, до сучасних зовнішніх загроз для національної фінансової безпеки слід додати незахищеність державних інтернетмереж та серверів в сфері фінансів від зовнішніх кібер-атак на банківські системи.

В свою чергу, до чинників, що можуть призвести до створення внутрішніх загроз національній фінансовій безпеці, нормотворець відносить: нестабільність та недосконалість правового регулювання у фінансовій сфері; нерівномірний розподіл податкового навантаження на суб'єктів господарювання, що зумовлює ухилення від сплати податків та відплив капіталу за кордон; відплив капіталу за кордон внаслідок погіршення інвестиційного клімату; низький рівень бюджетної дисципліни і незбалансованість бюджетної системи; збільшення обсягу державного боргу; тіні- зація економіки; недостатній рівень золотовалютних резервів; значний рівень доларизації економіки; істотні коливання обмінного курсу національної валюти, що не обумовлені дією макроекономічних факторів; слабкий розвиток фондового ринку; недостатній рівень капіталізації фінансової системи [1].

Даний перелік внутрішніх чинників, що загрожують національній безпеці, слід доповнити таким - перевищення допустимого рівня присутності іноземних банків в банківській системі держави, особливо банків однієї зарубіжної країни. Для України дане питання є актуальним, оскільки кількість банків Російської Федерації, що здійснювали діяльність на території України на 2014 рік складала суттєву, як для однієї країни, частку - приблизно 8-10\% [2], яка пізніше (з початком військових дій на Сході України) була скорчена майже вдвічі. За умов зростання даного показника могла настати небезпека можливості створення 3 боку РФ штучного дефолту або інших небезпек, а це є підставою вважати недосконалою роботу відповідних державних органів даного періоду щодо захисту національної фінансової безпеки України.

Аналіз вказаних положень Розпорядження КМУ чітко вказує на те, що зовнішній фактор є одним з основних чинників, який може призвести як до зовнішніх, так і до внутрішніх загроз. Особливо важливим в даному контексті є питання зовнішнього державного боргу, який, 3 одного боку, спричинює в певній мірі обмеження суверенітету (нехай і добровільне), оскільки міжнародні фінансові організації здійснюють кредитування держави за умови виконання нею реформ не тільки в економічній сфеpi, але і в інших сферах життя країни (наприклад, реформи в антикорупційній сфері тощо). 3 іншого боку, великий зовнішній борг держави стає суттєвим гальмуючим чинником для розвитку національної фінансової системи, оскільки обслуговування 
державного боргу та сплата відсотків по кредитах лягають важким тягарем на економіку країни. Тому, діяльність держави як суб'єкта міжнародного фінансового права підпорядкована не тільки принципам та нормам міжнародного фінансового права, але й здійснюється у відповідності до національних інтересів країни в сфеpi фінансів. 3 метою забезпечення ефективного функціонування національної фінансової системи та зростання економіки, держава діє на міжнародній арені у відповідності 3 обраними нею внутрішньодержавними стратегічними планами, концептуальними засадами та механізмами запобігання кризових явищ в сфері фінансів.

Саме керуючись власним національним інтересом в сфері фінансів, держава вступає в ті чи інші міжнародні фінансові відносини, а саме: стає членом міжнародних фінансових організацій, статутні цілі яких вона згідна виконувати; укладає міжнародні договори в фінансовій сфері тощо. Проте, для того, щоб на міжнародній арені діяти в національних інтересах, держава повинна володіти повною міжнародною правосуб'єктністю, одним з проявів якої є незалежність і самостійність. Незалежність фінансової системи, тобто здатність держави самостійно визначати цілі, механізми та шляхи їі функціонування, є, з одного боку, основним елементом фінансової безпеки України. 3 іншого боку, саме задля забезпечення нормального функціонування національної фінансової системи, а відповідно для захисту національної фінансової безпеки, держави, в силу взаємозалежності держав в фінансовій сфері та з метою забезпечення ефективного функціонування світової фінансової системи в умовах глобалізації, не можуть діяти абсолютно самостійно і незалежно, а тільки у відповідності до принципів та норм міжнародного фінансового права.

Аналіз сучасних міжнародних фінансових відносин свідчить про наявність різних причин для обмеження самостійності держав в цій сфері. Серед чинників, що обумовлюють певного роду обмеження державного фінансового суверенітету, є ті, що об'єктивно обумовлені реаліями сучасної міжнародної фінансової системи та тенденціями в міждержавному співробітництві. До таких чинників, насамперед, належать положення міжнародних документів, якими визначаються принципи співробітництва між державами та основи міжнародного фінансового правопорядку в цілому. Зокрема, статутні положення міжнародних фінансових організацій, в яких закріплені правила та вимоги щодо здійснення зовнішньої та внутрішньодержавної фінансової діяльності країн; Декларація про встановлення нового міжнародного економічного порядку від 1974 року, Хартія економічних прав та обов'язків держав від 1974 року, дотримання яких направлене на підтримку ефективного функціонування міжнародного фінансового правопорядку; низка двосторонніх договорів між країнами 3 фінансових питань та інші.

Іншою групою $є$ суб'єктивнообумовлені чинники, які тягнуть за собою обмеження самостійності держав щодо зовнішньої та внутрішньої фінансової політики внаслідок зовнішніх запозичень, отримання яких зобов'язує до проведення різного роду реформ та виконання інших вимог, що певним чином обмежує суверенну волю країн в тих чи інших фінансових сферах. В умовах глобалізації та інтеграції світової економіки, одним із напрямків залучення додаткових ресурсів для стабільного економічного розвитку країни є державні запозичення [3, с. 31]. Всі держави світу за критерієм зовнішнього фінансування можна умовно поділити на «фінансових донорів» і «фінансових реципієнтів». Багато країн виступають одночасно як донорами так і реципієнтами в фінансовій сфеpi. Питання державних запозичень лежить в основі багатьох міжнарод- 
них правовідносин в сфері фінансів та виступає чи не найважливішим внутрішньодержавним фінансовим питанням, особливо для «країн реципієнтів». На сучасному етапі розвитку світової економіки тенденція до постійного зростання державного боргу притаманна і економічно розвинутим країнам, i країнам що розвиваються [3, с. 31].

Фінансова безпека держави складається з таких елементів як: безпека грошово-кредитного сектору, бюджетна безпека, боргова безпека, безпека банківського ринку, безпека фондового сектору [4, с. 26]. Кожний елемент характеризується певними ключовими індикаторами, які застосовують при оцінці стану безпеки відповідної складової. Загальним індикатором фінансової безпеки є інтегральний показник, до якого входять всі показники складових елементів. Всі елементи фінансової безпеки держави мають важливе значення для ефективного функціонування національної фінансової системи. Серед них боргова безпека є складовим елементом як фінансової безпеки держави, так державного фінансового суверенітету, що, на наш погляд, виокремлює її з низки інших в силу визначальної ролі для національної безпеки країни. Так, недотримання граничних рівнів показників, що характеризують стан внутрішнього й зовнішнього боргу, порушення оптимального співвідношення між структурними його складовими, неможливість обслуговування зовнішнього боргу i, особливо, нехтування цільовою спрямованості запозичених коштів може призвести до руйнування вітчизняної фінансової системи та загрожувати суверенітету держави [3, c. 34].

Боргова політика, зазначає B.M. Шаповал, є потужним важелем забезпечення стійкого розвитку економіки, за умов суворого дотримання встановлених нормативних та кількісних параметрів [5, с.82]. Обмеження обсягу державного боргу прямо обумовлено захистом національної фі- нансової безпеки. Незважаючи на те, що в різних державах боргова національна політика має свою специфіку (наприклад, в Росії - направлена на зменшення державного боргу, в Японії - навпаки) [6], проте, в багатьох країнах на державному рівні закріплюється граничний обсяг державного боргу, перевищення якого ставить під загрозу фінансову безпеку країни. Загальний державний борг (прямий державний борг та гарантований) формується за рахунок внутрішнього боргу (державні позики та кредити від вітчизняних банків в національній валюті на внутрішніх ринках) i зовнішнього боргу (кредити та позики від іноземних держав та міжнародних організацій в іноземній валюті). Показник співвідношення зовнішнього і внутрішнього боргу держави до її ВВП характеризує рівень боргової безпеки країни [3, с. 34].

Науковці в сфері міжнародної економіки виділяють такі основні моделі інституційного забезпечення управління державним боргом як: 1) банківська модель - центральний банк країни здійснює управління державним боргом (Кіпр, Данія, Мальта); 2) урядова модель - управління державним боргом здійснює певна урядова структура (Чехія, Естонія, Іспанія, Литва, Люксембург, Польща, Словенія, Італія); 3) агентська модель - окрема структура (агентство) вибирає найоптимальніші методи управління державним боргом (Австрія, Бельгія, Фінляндія, Франція, Греція, Нідерланди, Ірландія, Латвія, Німеччина, Португалія, Словаччина, Швеція, Угорщина, Велика Британія) [7, с. 158].

Для Україн питання державного боргу в останні роки стало вкрай гострим. Його показники в період 2014-2017 років коливались в межах 70-80\% [6] від ВВП, що було перевищенням закріпленого в Бюджетному кодексі України граничного обсягу державного боргу та становило загрозу для фінансової безпеки України, а відповідно ї для іiї державного фінансового суверенітету. Від- 
повідно до статті 18 Бюджетного кодексу України, загальний обсяг державного боргу та гарантованого державою боргу на кінець бюджетного періоду не може перевищувати 60\% річного номінального обсягу валового внутрішнього продукту України. У випадку очікуваного перевищення цієї граничної величини Кабінет Мiністрів України невідкладно звертається до Верховної Ради України за дозволом про тимчасове перевищення такої граничної величини та подає для схвалення план заходів 3 приведення загального обсягу державного боргу та гарантованого державою боргу до встановлених вимог [9].

В положеннях Стратегії реформування системи управління державними фінансами на 2017-2020 роки зазначається: оскільки значний обсяг дефіциту державного бюджету вимагає постійних зовнішніх запозичень, що не дає змоги досягти показника загального державного боргу на рівні $60 \%$ ВВП, як це передбачено статтею 18 Бюджетного кодексу України, метою фінансової політики України на найближчі чотири роки є забезпечення боргової стійкості та зниження співвідношення державного боргу до ВВП до нормативно закріпленого показника [10]. Неадекватна структура державного боргу України та незважена політики в галузі державних запозичень нагально потребує розв'язання проблеми боргової залежності та фінансової безпеки України. Оскільки можливості зменшення боргового навантаження на економіку України через реструктуризацію не є безмежними, державна політика поступово повинна переходити від переоформлення платежів до стратегічного управління державним боргом. Однією 3 проблем виведення фінансової системи України на прийнятний рівень є те, що більше 84\% запозичень спрямовується на фінансування бюджетного дефіциту і близько 2\% на інвестування економіки. Така ситуація $€$ неприйнятною в контексті забезпечення економічного зростання та укріплення національ- ної фінансової системи. Тільки у 2018 році показник співвідношення зовнішнього боргу України до ВВП знизився до допустимої в законі межі $-60,9 \%$ [8].

Вибір засобів для досягнення національних потреб в сфері фінансів $\epsilon$ важливим питанням при формуванні свого інтересу. Незважаючи на схожу об'єктивну складову державного інтересу в сфері фінансів у окремих країн (однаковий стан національної фінансової системи, однаковий дефіцит бюджету та однакова потреба у зовнішніх запозиченнях), суб' єктивна складова часто різниться, оскільки усвідомлення державами необхідності вирішувати внутрішні проблеми за допомогою міждержавного співробітництва $є$ кардинально різним. Такі особливості є причиною різноманітності державних інтересів у держав під час міжнародного співробітництва. Міжнародна правова позиція держави, зазначає В. І. Евінтов, представляє собою сформовані під впливом об'єктивних та суб'єктивних факторів і відповідним чином реалізовані установки щодо застосування міжнародного права і його розвитку при здійсненні інтересів і цілей держави [11, с. 110].

Питання фінансової безпеки держави, зокрема їі забезпечення, впливає одночасно на внутрішню функцію держави та тісно пов'язане 3 iï зовнішньою функцією, яку держави виконують під час міжнародного співробітництва в сфері фінансів. Національній фінансовій безпеці несуть загрозу чинники: 1) зовнішнього характеру - суттєва залежність від зовнішніх кредиторів, зростання дефіциту платіжного балансу, суттєва залежність від експортно-імпортної діяльності, погіршення стану зовнішньої торгівлі, вплив світових фінансових криз на фінансову систему держави, незахищеність державних інтернет-мереж та серверів від зовнішніх кібер-атак на банківські системи; 2) внутрішнього характеру нестабільність та недосконалість правового регулювання у фінансовій 
сфері, внаслідок чого спостерігається погіршення інвестиційного клімату; нерівномірний розподіл податкового навантаження; тінізація економіки; незбалансованість бюджетної системи; збільшення обсягу державного боргу; недостатній рівень золотовалютних резервів; значний рівень доларизації економіки; істотні коливання обмінного курсу національної валюти, що не обумовлені дією макроекономічних факторів; слабкий розвиток фондового ринку; недостатній рівень капіталізації фінансової системи; значна присутність іноземних банків на національному банківському ринку держави.

До чинників, що здійснюють правовий обмежуючий вплив на зовнішній фінансовий суверенітет належать: 1) чинники, які об'єктивно- обумовлені нормативно-правовою складовою міжнародного фінансового правопорядку; 2) чинники, які суб'єктивно-обумовлені - виникли внаслідок зовнішніх запозичень держави.

Боргова безпека держави, рівень якої характеризує показник співвідношення зовнішнього і внутрішнього боргу держави до її ВВП, є одним 3 найважливіших складових, як фінансової безпеки держави, так державного фінансового суверенітету в цілому. Обмеження граничного обсягу державного боргу, перевищення якого становить загрозу фінансовій безпеці країни, закріплюється на державному ріні та прямо обумовлено захистом національної фінансової безпеки будь-якої країни.

\section{Список використаних джерел}

1. Розпорядження Кабінету Міністрів України «Про схвалення Концепції забезпечення національної безпеки у фінансовій сфері» № 569-р від 15.09.2012. [Електронний - ресурс]. Режим доступу: http://zakon3.rada.gov.ua/laws/show/569-2012$\% \mathrm{D} 1 \% 80$.

2. Російські банки: від любові до ненависті. [Електронний - ресурс]. Режим доступу: https://biz.nv.ua/ukr/experts/saygun/rosijski-banki-vid-ljubovi-do-nenavisti817847.html.

3. Фінансова безпека соціально-економічного розвитку держави: сучасні проблеми та стратегічні орієнтири. За заг. ред. д.е.н., проф. О. В. Чернявської. Вищий навч. заклад Укоопспілки «Полтавський університет економіки і торгівлі» (ПУЕТ) 2012. $362 \mathrm{c}$.

4. Єрмошенко М. М. Фінансова безпека держави: національні інтереси, реальні загрози, стратегія забезпечення К.: Изд-во КНТЕУ, 2001. 309 с.

5. Шаповал М. В. Стратегічні аспекти управління державним боргом // Наукові праці НДФІ. 2014. № 1 (66). С. 81-86.

6. Гедзь $О$. Зарубіжний досвід управління державним боргом та можливості його імплементації в Україні // Науковий блог Національного університету «Острозька академія». Електронний ресурс]. Режим доступу: https:/naub.oa.edu.ua/ 2015/зарубіжний-досвід-управління-держав/.

7. Козак Ю. Г., Лук'яненко Д. Г. Міжнародна економіка : посібник 2-ге вид., переробл. та доповн. К. : Центр навч. л-ри, 2004. 672 с.

8. Державний борг України. Міністерство фінансів України. https://index.minfin.com.ua/ua/finance/debtgov/2019.

9. Бюджетний кодекс України від 08.07.2010 № 2456-VI. [Електронний ресурс]. - Режим доступу: http://zakon2.rada.gov.ua/laws/show/2456-17

10. Розпорядження Кабінету Міністрів України Про схвалення Стратегії реформування системи управління державними фінансами на 2017-2020 роки [Електронний ресурс]. Режим доступу: від 8.02.2017 року № 142-p // http:// zakon2.rada.gov.ua/laws/show/142-2017-\%D1\%80/page?text=\%E1\%EE\% F0\%E3 
11. Евинтов В. И., Михайловский Н. К.: Международное сообщество и правопорядок. Анализ современных концепций. Киев: Наук.думка, 1990. 128 с.

Вайцеховська О. Р. Фінансова національна безпека як складова фінансового суверенітету держави

В статті проаналізовані зовнішні та внутрішні фактори негативного впливу на національну безпеку в фінансовій сфері. Досліджені складові елементи фінансової безпеки держави. Розкрито проблему зовнішнього боргу країни в контексті збереження національної фінансової безпеки та роль боргової політики країни у забезпеченні стійкого розвитку національної економіки. Досліджені об’єктивно-обумовлені та суб'єктивно-обумовлені чинники, що обмежують правосуб'єктність держави в міжнародному фінансовому правопорядку.

Ключові слова: фінансова безпека країни, національний фінансовий суверенітет, державний борг, дефіцит державного бюджету, боргова безпека.

Вайцеховская О. Р. Финансовая национальная безопасность как элемент финансового суверенитета государства

В статье проанализированы внешние и внутренние факторы негативного влияния на национальную безопасность в финансовой сфере. Исследованы составляющие элементы финансовой безопасности государства. Раскрыта проблема внешнего долга станы в контексте сохранения национальной финансовой безопасности, а также роль долговой политики страны в обеспечение стабильного развития национальной экономики. Исследованы объективно-обусловленные и субъективно-обусловленные причины ограничения правосубъектности государства в международном финансовом правопорядке.

Ключевые слова: финансовая безопасность государства, национальный финансовый суверенитет, государственный долг, дефицит государственного бюджета, долговая безопасность.

Vaitsekhovska $\mathrm{O}$. Financial national security as the basis for the state financial sovereignty

The article analyzes the external and internal factors that have a negative influence on national security in the financial sphere. The components of the state financial security are investigated. The problem of the external debt of the country in the context of maintaining the national financial security and the role of the country's debt policy in ensuring the sustainable development of the national economy is disclosed. Objectively and subjectively conditioned factors limiting the legal personality of the state in the international financial law and order are also investigated.

Keywords: financial security of the country, national financial sovereignty, state debt, the deficit of the state budget, debt security. 